\title{
Energy balance analysis on Rimbo Dua palm oil
}

\author{
Arif Hidayat $^{1, *}$, Ari Wibowo ${ }^{2}$, Saptyaji Harnowo ${ }^{3}$ \\ 1, 2, 3 Politeknik LPP, J1. Politeknik LPP 1A Balapan, Yogyakarta 55222, Indonesia \\ E-mail: $\underline{\text { arh@ @ polteklpp.ac.id * }}$ \\ * Corresponding Author
}

Palm Oil Mill is an industry that uses biomass as an energy generator to run the process. The biomass used is fiber, shells, and empty fruit bunches. Energy efficiency is needed in the process; therefore, it requires energy balance in the power generation system, distribution, and use of energy produced by biomass. PKS Rimbo Duo has a processing capacity of 30 tonnes/hour. Broadly speaking, the energy system at PKS Rimbo Dua includes steam energy production equipment such as boilers and steam and electricity energy conversion equipment in the form of steam turbines and generators (alternators) as well as storage equipment for the expansion of steam energy in the form of opposing pressure storage vessels (BPV). Energy balance analysis is carried out by analyzing data methods obtained from the performance of operating equipment and conducting field surveys and measurements of predetermined parameters, especially in boilers, water treatment, and turbines. Analysis of fuel use is also carried out to determine the quality of the fuel and the potential for steam produced. The result of this research is that the average efficiency of the boiler is $63.23 \%$, which is still below the $73 \%$ boiler design. One of the reasons is that the flue gas temperature reaches $260{ }^{\circ} \mathrm{C}$. The steam turbine has an efficiency of $44 \%$ isentropically with SSC $=31.9 \mathrm{~kg} / \mathrm{kWh}$ when compared to the standard norm, the SSC value is still too high. The results of the water analysis also found the $\mathrm{P}$ and $\mathrm{M}$ alkalinity values, and the water $\mathrm{pH}$ was still 9.8. The results of the analysis of these data can be used as a reference for actions whether it is a repair of equipment, replacement of equipment, and improvement of operational parameters.

This is an open-access article under the CC-BY-SA license.

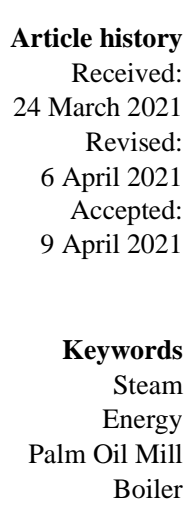

\section{Introduction}

The Palm Oil Mill (PKS) has its energy generation system which uses biomass by-products as fuel. The biomass that becomes the fuel is such as fiber, shell, and tanks. In the calculation of the energy generation in the Palm Oil Mill, the biomass used as fuel should be sufficient to become fuel in the energy generation process. The oil palm biomass particularly PS, MF, and EFB have a high potential to be readily used as a source for RE production [8]. In factories with good energy generating equipment efficiency, Palm Oil Mill (PKS) will get other income from the residual shell which has a fairly profitable economic value. Palm oil residues (fruit fiber, palm kernel shells, and empty fruit bunches) were characterized by proximate analysis and calorific value [13]. For increasing the power efficiency of the plants, mainly by increasing steam parameters 
Journal of Engineering and Applied Technology

Vol. 2, No. 1, March 2021, pp. 13-22

and the installed power in cogeneration plants and reducing steam consumption in the process [3].

Rimbo Dua Palm Oil Mill (PKS) currently has an installed capacity for palm oil processing of 30 Ton/Hour and the latest data is in 1 month of August 2019 with an average processing capacity of 24 Tons tbs/hour. Utility equipment for generating energy balance consists of the main tool of the boiler as a steam generator with normal operation at pressure. Rimbo Dua Palm Oil Mill (PKS) has 1 (one) unit of steam power plant with a total installed capacity of 25 Tons/Hour of steam with a steam pressure of $21 \mathrm{Kg} / \mathrm{cm}^{2}$. The average processing capacity of Rimbo Dua Palm Oil Mill was taken in August 2018 when the maximum turbine load due to operating the Bunch Press Station was 23,68 Tons/Hour. The more CPO produced the more palm oil biomass waste. A POM removes about 12 to $15 \%$ fiber, 5 to $7 \%$ shell, and 20 to $23 \%$ EFB based on its capacity [11].

Seeing the potential to increase the efficiency of the generating equipment and the last average processing capacity that does not reach the capacity of the installed equipment, it is necessary to carry out an analysis aimed at seeing the energy balance that occurs in the Rimbo Dua Palm Oil Mill by looking at the potential for fuel and analyzing the efficiency of the generator energy. Decentralized power generation from biomass could be an alternative for communities in remote areas and could help transform the local economy and the activities and lifestyle of local populations [12].

\section{Method}

In carrying out an audit of industrial energy balance at Rimbo Dua Palm Oil Mill (PKS), it is carried out under the audit Standard Operating Procedures as follows:

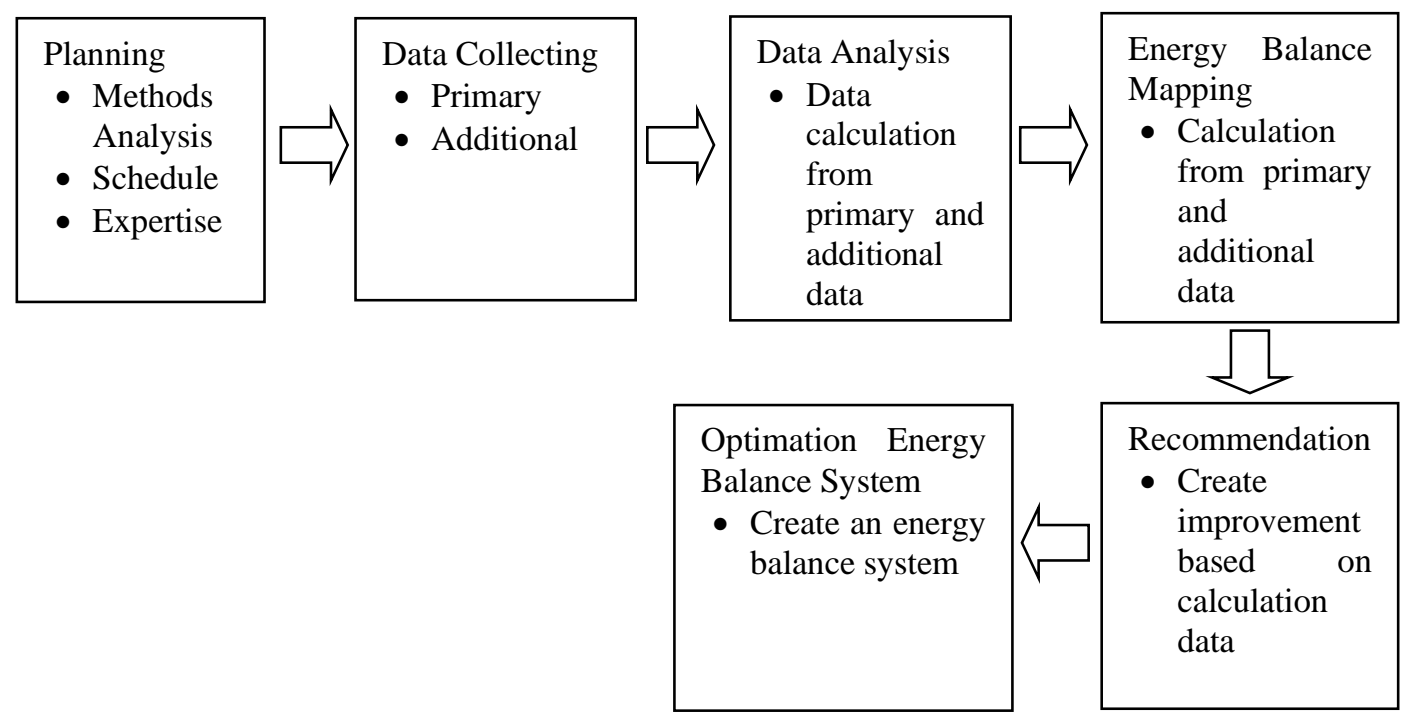

Fig. 1. Energy balance audit methods

The initial process of evaluating the energy balance in Rimbo Dua Palm Oil Mill (PKS) is the analysis of the performance data of the energy generating unit and the steam balance as well as the mass balance of solid and liquid waste products as the main potential energy source for Palm Oil Mill (PKS) processing. The data required in the analysis process are factory performance data and direct measurement data of several parameters taken or sampled directly during the field 
survey. Analysis of the energy balance performance data of Rimbo Dua Palm Oil Mill (PKS) was carried out at several observation points and calculations including actual boiler operational data, actual data on turbine operations, actual data on operational water treatment, boiler efficiency, and fuel analysis data. As for the reference for steam production at the Rimbo Dua Palm Oil Mill (PKS), this has been done by burning the fiber and shells that come out of the press station as fuel for the boiler (steam boiler). The amount of steam that can be generated from a fiber and shell-fired boiler in a Palm Oil Factory depends on the amount of fiber and shells produced, the quality of the fiber and shells in the form of moisture content, and the steam conditions (temperature and pressure) coming out of the boiler want to achieve. Rimbo Dua Palm Oil Mill (PKS) has 1 (one) steam generator unit with a total installed capacity of 25 tons/hour of steam with a steam pressure of $21 \mathrm{Kg} / \mathrm{cm} 2$. The average capacity of Rimbo Dua Palm Oil Mill (PKS) was taken in August 2018 when the maximum turbine load due to operating the Bunch Press station was 23,69 tons/hour.

\subsection{Boiler design dan Actual Condition}

Initial observations were made from the actual operational data of the boiler which is a steam generating unit. What is done is the observation of steam temperature, intake water temperature, duct flue gas temperature, data on the amount of fuel, data on the amount of steam, load data, and other required data including steam saturation temperature, duct gas temperature, and chimney temperature. Observation of boiler steam to determine temperature so that the enthalpy output is known for calculating boiler efficiency.
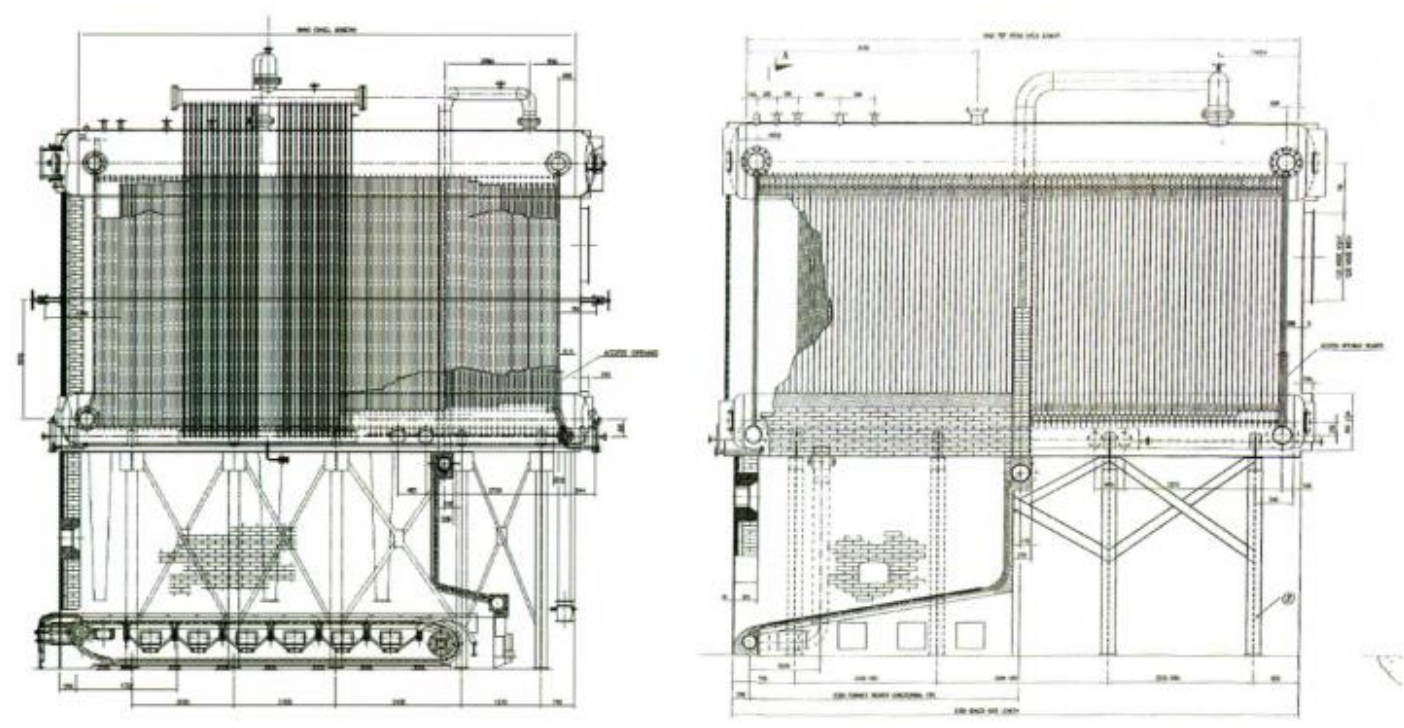

Fig. 2. Maxitherm water tubes boiler

\subsection{Fuel Analysis}

Fuel analysis is an analysis of the characteristics of the fuel used in the energy generation process and of course has certain criteria. The fuels used are fiber, shells, and EFB.

\subsection{Water Analysis}

Water is one of the important factors that determine the performance of a steam generator, especially boiler operations because there is the ugliness that occurs due to water that does not comply with the requirements. Water as a boiler needs is divided into two, namely boiler feed 
water (boiler make up water) and boiler water. The requirements for boiler fill water and boiler water for boiler pressure of 20 bar, for the ABMA, British, and JIS (Japan) standards are as follows:

Table 1. Requirements for boiler feedwater

\begin{tabular}{|c|c|c|c|}
\hline Parameter & $\begin{array}{c}\text { ABMA } \\
(310-450 \text { psig })\end{array}$ & $\begin{array}{l}\text { British Std } \\
(20-40 \text { bar })\end{array}$ & $\begin{array}{c}\text { JIS } \\
(20-30 \text { bar })\end{array}$ \\
\hline $\mathrm{pH}$ (Unit) & - & $8.5-9.5$ & $7.0-9.0$ \\
\hline $\begin{array}{l}\text { T. Hardness } \\
\left(\mathrm{ppm} \mathrm{CaCO}_{3}\right)\end{array}$ & 0.3 & 2 & 0 \\
\hline T. Iron (ppm Fe) & $<0.1$ & - & 0.1 \\
\hline $\begin{array}{l}\text { Dissolved Oxygen } \\
\quad\left(\mathrm{ppm} \mathrm{O}_{2}\right)\end{array}$ & - & $<0.02$ & - \\
\hline Oil & 0 & 0 & 0 \\
\hline \multicolumn{4}{|c|}{ Table 2. Requirement boiler water } \\
\hline Parameter & $\begin{array}{c}\text { ABMA } \\
(310-450 \text { psig) }\end{array}$ & $\begin{array}{l}\text { British Std } \\
(20-40 \text { bar })\end{array}$ & $\begin{array}{c}\text { JIS } \\
(20-30 \text { bar })\end{array}$ \\
\hline $\mathrm{pH}$ (Unit) & - & & $10.5-11.0$ \\
\hline Conductivity & 3500 & $2000-3000$ & $<1000$ \\
\hline $\begin{array}{l}\text { M-Alkalinity } \\
\left(\mathrm{ppm} \mathrm{CaCO}_{3}\right)\end{array}$ & NS & $500-700$ & $<150$ \\
\hline $\begin{array}{l}\text { O-Alkalinity } \\
\left(\mathrm{ppm} \mathrm{CaCO}_{3}\right)\end{array}$ & - & 150 & $<80$ \\
\hline $\begin{array}{c}\text { Silica } \\
\left(\mathrm{ppm} \mathrm{SiO}_{3}\right)\end{array}$ & $<90$ & $<0.4 \mathrm{x}$ “O” Alk & $<50$ \\
\hline $\begin{array}{c}\text { Sulfite } \\
\left(\mathrm{ppm} \mathrm{SO}_{3}\right)\end{array}$ & & $20-50$ & $5-10$ \\
\hline $\begin{array}{l}\text { Phosphate } \\
\left(\mathrm{ppm} \mathrm{PO}_{3}\right)\end{array}$ & & $30-70$ & $5-15$ \\
\hline
\end{tabular}

\subsection{Boiler actual efficiency}

In general, the standard calculation of efficiency does not include blowdown as losses. Basically, boiler efficiency can be tested using the ASME Standard method: PTC-4-1 Power Test Code for Steam Generating Units, namely Direct Method and Indirect Method.

1. Direct Methods

In general, the standard calculation of efficiency does not include blowdown as losses. Basically, boiler efficiency can be tested using the ASME Standard method: PTC-4-1 Power Test Code for Steam Generating Units, namely Direct Method and Indirect Method:

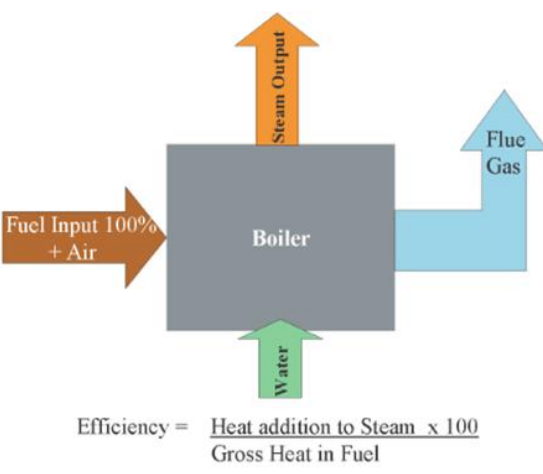

Boiler Efficiency $=\frac{\text { Steam flow rate } \mathrm{x}(\text { steam enthalpy }- \text { feed water enthalpy })}{\text { Fuel firing rate } \mathrm{x} \text { Gross calorific value }} \times 100$

Fig. 3. Efficiency Calculation with Direct Method 


\section{Indirect Methods}

Calculated by analyzing each loss that occurs in the boiler. Indirect boiler efficiency analysis is an efficiency analysis by calculating the total losses that occur during the steam generation process. The losses are flue gas losses, $\mathrm{H} 2$ losses in fuel, moisture losses in fuel, moisture losses in the air, ash losses, blowdown, etc. the indirect losses boiler schematic is shown in Fig.4.

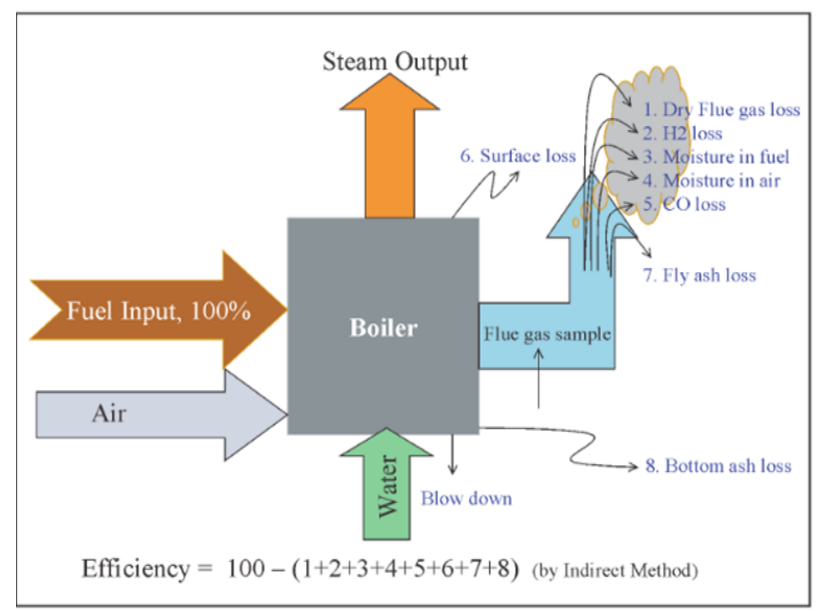

Fig. 4. Efficiency calculation with the indirect method

3. Turbine Performance

In addition to boiler operational data, in energy balance, the performance of the turbine is also seen, while the turbine test parameters are isentropic value, wetting efficiency, and turbine efficiency as well as SSC.

4. Actual Mass and Steam Balance

Performed by the method of analysis carried out in the PAU UGM Laboratory and calculated using pre-existing data.

\section{Results and Discussion}

\subsection{Boiler Actual Condition}

The following is all survey data from the actual operational conditions of the Rimbo Dua Palm Oil Mill (PKS) boiler:

Table 3. Boiler datasheet

\begin{tabular}{clccc}
\hline No & Data & Unit & Design & Actual \\
\hline 1 & Steam Flow & $\mathrm{Ton} / \mathrm{h}$ & 25 & - \\
2 & Pressure Output & $\mathrm{Kg} / \mathrm{cm}^{2}$ & 20 & 19 \\
3 & Temperature Output & $\mathrm{C}$ & 260 & 300 \\
4 & Feed Water Pressure & $\mathrm{Kg} / \mathrm{cm}^{2}$ & 25 & 21 \\
5 & Temperature Feed Water & $\mathrm{C}$ & 100 & 62 \\
6 & Temperature Flue Gas & $\mathrm{C}$ & & 260 \\
7 & $\mathrm{O}_{2}$ In Flue Gas & $\%$ & & 12.5 \\
8 & $\mathrm{CO}_{2}$ In Flue Gas & $\%$ & & 4.7 \\
9 & CO In Flue Gas & $\mathrm{ppm}$ & & 100 \\
10 & Percentage of Shell \& Fibre & $\%$ & & 100 \\
& Burned & &
\end{tabular}


Journal of Engineering and Applied Technology

Vol. 2, No. 1, March 2021, pp. 13-22

The feed water also shows a low temperature of $62^{\circ} \mathrm{C}$ and a normative flue gas temperature of $260{ }^{\circ} \mathrm{C}$ indicating high losses to the flue gas and large oxygen content to the flue gas of $12,5 \%$, indicating a high need for excess air into the boiler kitchen. This will trigger the potential for lower boiler efficiency with smaller steam generated results.

\subsection{Fuel Analysis}

Table 4. Fuel analysis

\begin{tabular}{llccccc}
\hline No & & $\begin{array}{c}\text { Ash } \\
(\boldsymbol{\%})\end{array}$ & $\begin{array}{c}\text { Moisture } \\
(\boldsymbol{\%})\end{array}$ & $\begin{array}{c}\text { Volatile } \\
(\boldsymbol{\%})\end{array}$ & $\begin{array}{c}\text { Carbon } \\
(\boldsymbol{\%})\end{array}$ & GCV \\
\hline 1 & Shell & 1.57 & 16.72 & 53.88 & 27.83 & 3814.97 \\
& & 1.47 & 16.21 & 55.68 & 26.64 & 3864.00 \\
& & 1.52 & 16.46 & 54.78 & 27.24 & 3839.49 \\
2 & \multirow{2}{*}{ Fiber } & 2.84 & 55.48 & 29.65 & 12.03 & 2118.54 \\
& & 2.49 & 52.76 & 31.79 & 12.96 & 2111.10 \\
& & 2.66 & 54.12 & 30.72 & 12.50 & 2114.82 \\
3 & \multirow{3}{*}{ Empty Fruit Bunch } & 1.27 & 69.35 & 21.54 & 7.84 & 1164.26 \\
& & 1.16 & 72.01 & 19.44 & 7.39 & 1261.10 \\
& & 1.22 & 70.68 & 20.49 & 7.61 & 1212.68 \\
4 & \multirow{3}{*}{ Fuel Proximate } & 2.26 & 40.94 & 39.14 & 17.66 & 2718.45 \\
\hline
\end{tabular}

Table 4 shows that the heating value varies. Some fiber shows high moisture interferes with the combustion process in the boiler furnace. Pressed Empty Fruit Bunch from Bunch Press has a high water content so it is not good if used directly as boiler fuel. With a high FC (Bonded Carbon), the GCV calorific value of the fuel tends to be greater. With a larger VM (Volatile Matter), the GCV calorific value tends to be greater. With greater MC (Moisture Content), the GCV value tends to decrease. With greater ash content, the GCV calorific value of the fuel tends to decrease. In PKS processing, the boiler fuel content is strongly influenced by the operational working pressure of the Pressman device and the temperature of the dilution water so that it needs to be maintained under norms.

\subsection{Water Analysis}

Table 5. Water analysis

\begin{tabular}{lccccccccccc}
\hline \multirow{1}{*}{ Sample } & \multicolumn{2}{c}{ Alkalinity M } & \multicolumn{2}{c}{ Phosphate } & \multicolumn{2}{c}{ Silikat } & \multicolumn{2}{c}{$\mathbf{p H}$} & \multicolumn{2}{c}{ Alkalinity P } \\
& Value & Std & Value & Std & Value & Std & Value & Std & Value & Std \\
& & & & & & & & & & \\
\hline Raw water & 26.0 & - & 0.28 & - & 62.56 & - & 6.23 & - & 0 & - \\
Feed Water & 16.0 & - & 0.39 & - & 53.72 & - & 5.75 & $7-9$ & 0 & - \\
Boiler Water & 186.0 & $<150$ & 0.39 & 0.39 & 536.51 & $<90$ & 9.49 & $10.5-11$ & 88.0 & $<80$ \\
\hline
\end{tabular}

The $\mathrm{pH}$ prerequisite for Feed Boiler Water is 7-9 while for Boiler Water is 10,5-11. Based on the results of laboratory analysis, the $\mathrm{pH}$ of Feed Boiler Water does not meet the criteria, this results in the addition of excessive $\mathrm{NaOH}$ in the internal treatment so that the TDS of boiler water will be rapidly increasing, the effect of exhausting the vapor is lost due to more and more blowdown.

Based on the water quality analysis carried out, it was found that the alkalinity value exceeded the maximum limit. This excess alkalinity value can lead to a tendency to create scale due to excess carbonate, so what needs to be done is to regulate the addition of $\mathrm{NaOH}$ in the internal treatment. 
According to the analysis, the phosphate content is far below the standard, this can cause scaling due to carbonate and sulfate salts easily. The thing that needs to be done in improving the boiler water management system is the addition of a phosphate treatment system in the internal treatment.

The silicate content in boiler water the exceeds the standard can cause scaling. Based on the results of the analysis, the silicate content in boiler water is very high, reaching values of more than $200 \mathrm{ppm}$. It is of great concern that the scale formation process in the boiler pipes takes place very quickly. What must be done is to evaluate the hardness removal system at WTP and improve the process and the does of $\mathrm{NaOH}$ that is added to increase the $\mathrm{pH}$ in the internal treatment.

\subsection{Boiler Actual Efficiency}

Table 6. Boiler actual efficiency

\begin{tabular}{lcc}
\hline \multicolumn{1}{c}{ Parameter } & Maxiterm Boiler & Unit \\
\hline L1(Dry Flue Gas) & 17 & $\%$ \\
L2 (Hydrogen In Fuel) & 7.72 & $\%$ \\
L3 (Moisture In Fuel) & 10.29 & $\%$ \\
L4 (Uncounted Loss) & & $\%$ \\
L5 (Uncounted Loss) & 0.5 & \\
L6 (Uncounted Loss) & & \\
L7 (Radiation and Convection) & 0.04 & $\%$ \\
L8 (Bottom and Fly Ash) & 0.60 & $\%$ \\
Losses Total & 36.15 & $\%$ \\
Efficiency & 63.85 & $\%$ \\
CGV & 2718.45 & $\mathrm{Kcal} / \mathrm{kg}$ \\
Temp. Ambient & 39 & $\mathrm{C}$ \\
C & 0.294 & $\%$ \\
H & 0.034 & $\%$ \\
O & 0.244 & $\%$ \\
Cp Flue Gas & 0.230 & $\mathrm{Kcal} / \mathrm{kg} \mathrm{C}$ \\
Theoretical Air & 3546 & $\mathrm{Kg} \mathrm{air} / \mathrm{kg}$ fuel \\
Excess Air & 1490 & $\%$ \\
Actual Mass Air Supply & 8828 & $\mathrm{Kg} \mathrm{air} / \mathrm{kg}$ fuel \\
Mass Flue Gas & 9091 & $\mathrm{Kg} \mathrm{flue} \mathrm{gas} / \mathrm{kg}$ fuel \\
GCV Fly Ash & 451500 & $\mathrm{Kcal} / \mathrm{kg}$ \\
GCV Bottom Ash & 800 & $\mathrm{Kcal} / \mathrm{kg}$ \\
\hline
\end{tabular}

From the results of the losses analysis, it can be seen that the total losses reached $36,7 \%$, the highest losses to flue gas reached $17,00 \%$, the normative exhaust gas temperature was $260{ }^{\circ} \mathrm{C}$, this needs to be ensured regarding boiler operations by keeping the generating pipe clean by periodically performing soot blower operation, while losses due to the water content in the fuel mainly fiber, must be ensured for the performance of the pressure and the water dilution temperature. For losses, the hydrogen content in the fuel is existing, so it can not be controlled.

\subsection{Turbine Performance}

The results of the turbine performance analysis are shown in Table 7.

Table 7. Actual turbine performance

\begin{tabular}{ccccccccccc}
\hline Type Merk & $\begin{array}{c}\text { Power } \\
(\mathbf{k W})\end{array}$ & Load & $\begin{array}{c}\text { Power } \\
\text { Used }\end{array}$ & $\begin{array}{c}\text { Isent } \\
\text {. Eff }\end{array}$ & h1 & Phase & h2 & Phase & $\begin{array}{c}\text { SSC } \\
\text { Isent }\end{array}$ & $\begin{array}{c}\text { Moist. } \\
\text { Eff }\end{array}$ \\
\hline $\begin{array}{l}\text { Superheated Coppus } \\
\text { Turbine }\end{array}$ & 1000 & $41 \%$ & $405 \mathrm{~kW}$ & $44 \%$ & 3050 & Superheated & 2907,6 & Superheated & 25,28 & $44 \%$ \\
\hline
\end{tabular}


Analysis of the performance of the Rimbo Dua steam turbine, with an isentropic approach of about $44 \%$ and because the turbine is installed with a superheat type, the wetness efficiency is $0,0 \%$, the turbine efficiency is $44 \%$ when compared to the ideal number, the turbine efficiency has decreased enough to reach 50-53\% design and SSC above is still normal with a turbine load of $41 \%$ to its full load.

\subsection{Actual Mass and Steam Balance}

Table 8. Actual mass and steam balance

\begin{tabular}{lcc}
\hline \multicolumn{1}{c}{ Parameter } & Maxitherm Superheated & Unit \\
\hline Eff Boiler Indirect Method & 63,25 & $\%$ \\
Shell Calorie & 27.090 .399 & $\mathrm{KJ} / \mathrm{jam}$ \\
Fibre Calorie & 27.580 .637 & $\mathrm{KJ} / \mathrm{jam}$ \\
Boiler Pressure & 19 & $\mathrm{Bar}$ \\
Boiler Temperature & 310 & ${ }^{\circ} \mathrm{C}$ \\
Steam Enthalpy & 3.050 & $\mathrm{KJ} / \mathrm{kg}$ \\
Water Pressure & 21 & $\mathrm{Bar}$ \\
Water Temperature & 62 & $\mathrm{oC}$ \\
Water Entalphy & 261 & $\mathrm{KJ} / \mathrm{kg}$ \\
Delta Entalphy & 2.789 & $\mathrm{KJ} / \mathrm{kg}$ \\
Steam generated by the Boiler & 13.343 & $\mathrm{KJ} / \mathrm{jam}$ \\
Daya Turbin & 405 & $\mathrm{KW}$ \\
SSC Actual & 31,9 & $\mathrm{Kg} / \mathrm{kWh}$ \\
Steam Boiler/TBS & 560 & $\mathrm{Kg} / \mathrm{ton}$ tbs \\
kW/TBS & 21,0 & $\mathrm{~kW} / \mathrm{ton}(+\mathrm{Genset})$ \\
Turbine Efficiency & 41 & $\%$ \\
Isentropic Efficiency & 44 & $\%$ \\
Mechanical Efficiency & 93 & $\%$ \\
\hline
\end{tabular}

With the above result approach with the input parameters of steam pressure and temperature, the boiler efficiency is still low $63,25,5 \%$, capable of producing a steam capacity of 12,448 $\mathrm{Kg} /$ hour, if all is converted into $495 \mathrm{KW}$ real power from a $90 \mathrm{~kW}$ generator to become a 405 $\mathrm{KW}$ turbine, then we will get the actual turbine SSC 31,9 Kg/Kwh, 23,1 kW/ton FFB electric power and steam for the process at BPV, $560 \mathrm{Kg} /$ ton FFB.

\section{Conclusion}

Based on the analysis of energy equilibrium calculations at the Rimbo Dua Palm Oil Mill. The average boiler efficiency is relatively low at $63.23 \%$ compared to the design (73\%), this is because the total boiler losses are $36.77 \%$ with the largest losses to flue gas still high $(17,08 \%)$, because the exhaust gas temperature reaches $260^{\circ} \mathrm{C}$, with the oxygen condition in the exhaust gas is still high, reaching $12.5 \%$ and requires excess air of $45.2 \%$. For boiler support water, the alkalinity and silicate levels are obtained above the standard which allows the scale to occur in the boiler pipe and reduces the efficiency of the boiler.

The steam turbine, has an efficiency of around $44 \%$ (isentropic eff) with $\mathrm{SSC}=31,9 \mathrm{Kg}$ / $\mathrm{kWh}$, at a load of $405 \mathrm{~kW}$, this number is not performing well, so it is necessary to follow up by looking at the performance in the last few years and the level of turbine damage when this is for all alternatives to replace a new turbine capable of producing SSC $24-27 \mathrm{Kg} / \mathrm{kWh}$ (standard norm) so that with an increase in processing capacity, the SSC will decrease and its performance will be better. 
Journal of Engineering and Applied Technology

Vol. 2, No. 1, March 2021, pp. 13-22

The results of water analysis for the boiler utility system are still some that do not meet the requirements, especially the $\mathrm{P} \& \mathrm{M}$ alkalinity and silicate content, and the $\mathrm{pH}$ of the boiler water is still low 9,8, it needs to be rechecked the operational procedures of the WTP and repair of the damaged WTP system.

The results of the analysis above can be used as a reference in the future to take several actions such as repair and maintenance of power plants and also maintaining standard operating parameters to improve efficiency and smooth operation of the plant.

\section{References}

[1] A. Abdulrazik, M. Elsholkami, A. Elkamel, and L. Simon, "Multi-products productions from Malaysian oil palm empty fruit bunch (EFB): Analyzing economic potentials from the optimal biomass supply chain," Journal of Cleaner Production, vol. 168, pp. 131148, 2017, doi: 10.1016/j.jclepro.2017.08.088.

[2] N. Aghamohammadi, S. S. Reginald, A. Shamiri, A. A. Zinatizadeh, L. P. Wong, and N. M. B. N. Sulaiman, "An investigation of sustainable power generation from oil palm biomass: A case study in Sarawak," Sustainability (Switzerland), vol. 8, no. 5, pp. 1-19, 2016, doi: 10.3390/su8050416.

[3] F. R. P. Arrieta, F. N. Teixeira, E. Yáñez, E. Lora, and E. Castillo, "Cogeneration potential in the Columbian palm oil industry: Three case studies," Biomass and Bioenergy, vol. 31, no. 7, pp. 503-511, 2007, doi: 10.1016/j.biombioe.2007.01.016.

[4] M. Aziz, T. ODA, and T. KASHIWAGI, "Design and Analysis of Energy-Efficient Integrated Crude Palm Oil and Palm Kernel Oil Processes," Journal of the Japan Institute of Energy, vol. 94, no. 1, pp. 143-150, 2015, doi: 10.3775/jie.94.143.

[5] P. Booneimsri, K. Kubaha, and C. Chullabodhi, "Increasing power generation with enhanced cogeneration using waste energy in palm oil mills," Energy Science and Engineering, vol. 6, no. 3, pp. 154-173, 2018, doi: 10.1002/ese3.196.

[6] Hariyanto, E. R. Purba, P., and B. Prasetyo, "Energy Saving through Implementation and Optimization of Small and Medium Scale Cogeneration Technology," KnE Energy, vol. 2, no. 2, p. 94, 2015, doi: 10.18502/ken.v2i2.362.

[7] S. Harnowo, "Analisis Kinerja Pembangkit Listrik Tenaga Biomasa Sawit (PLTBS) Pabatu PT Perkebunan Nusantara IV," Jurnal Mekanika dan Sistem Termal, vol. 1, no. 1, pp. 14-20, 2016.

[8] S. K. Loh, "The potential of the Malaysian oil palm biomass as a renewable energy source," Energy Conversion and Management, vol. 141, pp. 285-298, 2017, doi: 10.1016/j.enconman.2016.08.081.

[9] Mahidin et al., "Analysis of power from palm oil solid waste for biomass power plants: A case study in Aceh Province," Chemosphere, vol. 253, p. 126714, 2020, doi: 10.1016/j.chemosphere.2020.126714.

[10] N. Nasrin, A.B, Ravi, "of the Performance and Potential Export Renewable Energy (RE) From Typical Cogeneration Plant Used in Palm Oil Mills," Journal Of Engineering and Applied Sciences, vol. 6, pp. 433-439, 2011.

[11] M. A. Nasution, T. Herawan, and M. Rivani, "Analysis of palm biomass as electricity from palm oil mills in north Sumatera," Energy Procedia, vol. 47, pp. 166-172, 2014, doi: 10.1016/j.egypro.2014.01.210. 
[12] R. C. de Oliveira, R. D. de S. e Silva, and M. E. D. L. Tostes, "A methodology for analysis of cogeneration projects using oil palm biomass wastes as an energy source in the Amazon," Dyna, vol. 82, no. 190, pp. 105-112, 2015, doi: 10.15446/dyna.v82n190.43298.

[13] E. J. Ordoñez-Frías, J. A. Azamar-Barrios, E. Mata-Zayas, O. Silván-Hernández, and L. Pampillón-González, "Bioenergy potential and technical feasibility assessment of residues from oil palm processing: A case study of Jalapa, Tabasco, Mexico," Biomass and Bioenergy, vol. 142, no. October 2019, 2020, doi: 10.1016/j.biombioe.2020.105668.

[14] S. D. Panjaitan, "A Study on the Potential of Electrical Energy based on Gasification Technology from Oil Palm Empty Fruit Bunch in Landak West Kalimantan," The International Journal Of Engineering and Science, pp. 43-50, 2019, doi: 10.9790/18130803024350 .

[15] A. D. Santoso, "Evaluasi Kinerja Pabrik Kelapa Sawit Dalam Produksi Energi Terbaharukan," Jurnal Teknologi Lingkungan, vol. 19, no. 2, p. 213, 2018, doi: 10.29122/jtl.v19i2.2838.

[16] K. Suzuki, N. Tsuji, Y. Shirai, M. A. Hassan, and M. Osaki, "Evaluation of biomass energy potential towards achieving sustainability in biomass energy utilization in Sabah, Malaysia," Biomass and Bioenergy, vol. 97, pp. 149-154, 2017, doi: 10.1016/j.biombioe.2016.12.023.

[17] A. Wibowo, "Perancangan Sistem Pembangkit Listrik Biomassa Sawit ( PLTBS ) Kapasitas 5 MW," Mekanika dan Sistem termal (JMST), vol. 1, no. 2, pp. 53-60, 2016.

[18] Q. Wu, T. C. Qiang, G. Zeng, H. Zhang, Y. Huang, and Y. Wang, "Sustainable and renewable energy from biomass wastes in the palm oil industry: A case study in Malaysia," International Journal of Hydrogen Energy, vol. 42, no. 37, pp. 23871-23877, 2017, doi: 10.1016/j.ijhydene.2017.03.147.

[19] Yusniati, L. Parinduri, and O. K. Sulaiman, "Biomass analysis at palm oil factory as an electric power plant," Journal of Physics: Conference Series, vol. 1007, no. 1, 2018, doi: 10.1088/1742-6596/1007/1/012053. 